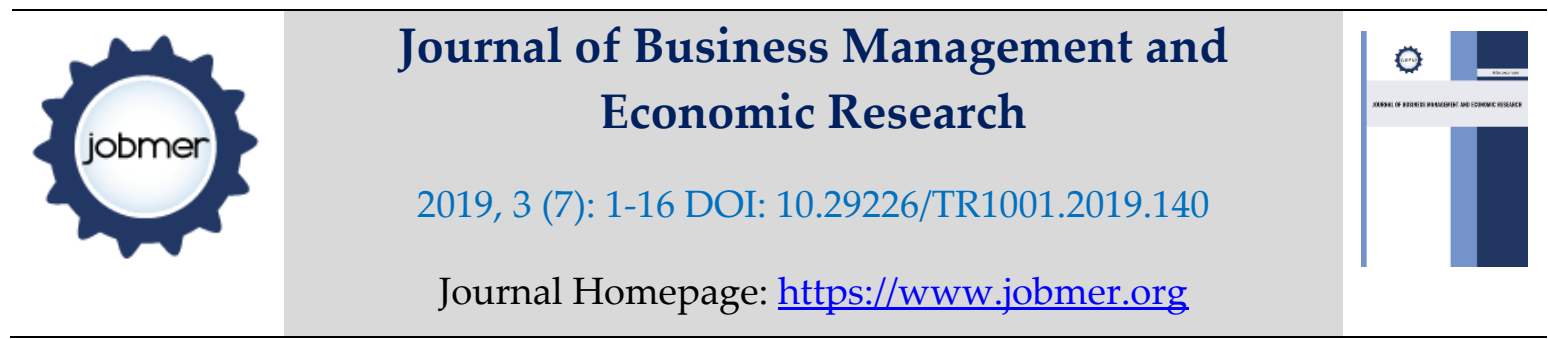

\title{
The Impact of Corporate Visibility on Image and Credibility of Radio Stations in the Kumasi Metropolis
}

\author{
Amoako-Agyeman K. N. \\ Department of Communication Design, \\ Kwame Nkrumah University of Science and Technology \\ kamook22@gmail.com
}

Adinkrah, L. K. K.

Angel Broadcast Network

Kumasi

Eshun, E. F.

Department of Communication Design,

Kwame Nkrumah University of Science and Technology

Kumasi, Ghana

\begin{abstract}
The study focus was to examine audience perception of corporate visibility of radio stations, and its impact on the image and credibility of radio stations in the Kumasi Metropolis, Ghana. Based on quantitative approach, data was collected from 385 respondents (managers of radio stations and radio listeners), and analysed based on both descriptive and inferential statistical tests. The results revealed that most of the radio stations had in place corporate visibility strategies. Though some respondents could not attest to the link between such strategies and visibility, corporate visibility was found to influence corporate image and credibility positively and in a statistically significant relationship. The results suggest a linear dependence of corporate image and credibility on corporate visibility. The implication is that increasing and improving corporate visibility has potential to strengthen corporate image and credibility. Recommendations include the development of customeroriented service which stresses on good corporate visibility and image-building to influence public perception and choice.
\end{abstract}

Keywords: Radio station, visibility, credibility, perception 


\section{Introduction}

Corporate identity, brand visibility, corporate image and credibility have become core characteristics of today's organizations in their quest to create a distinguishing character and experience for their target customers and consumers in a pluralistic marketplace. These concepts have become underlying issues for management and scholarly concern over the past decades cutting across various organizational goals and concerns (Kostamo, 2013).

Again, they have become central to academic disciplines like design thinking and communication, strategic management, marketing, communication, public relations and organizational behaviour. Such issues in Marketing are considered core to organizational strategy, credibility, stakeholder support and as tools for gaining a competitive advantage in the business environment as audiences rely on same in making decisions regarding investment, patronage, career and product choice (Melewar, 2003). For firms such as radio stations to deliver their full value to their clients and audiences, scholars opine that issues pertaining to corporate identity, reputation and image as brand visibility need to be acknowledged and well managed just like other strategic resources (Melewar, 2003).

Media practice worldwide has been transformed, taking the role as the fourth realm of power and has a lot of relevance in Ghana, facilitating real time information flow, entertainment and in education on a range of relevant issues. With increasing number of radio stations in Ghana regions, most entrants face challenges about creating unique identity, strong and identifiable brand to remain appealing to majority of listening audience to ensure profitability. Organizational visibility has been identified as an important element of modern business management literature with several scholars hypothesizing its contribution to reducing the degree of asymmetry between managers and other stakeholders (Brammer \& Millington, 2006).

Whilst new technologies enable self-expressing of users in real time, establish network ties and develop new relationships, satisfying the needs of traditional electronic media, radio listenership is predicted to run into significant drops in public patronage especially among the youthful class (Yang \& Kent, 2014). This new change in technology has disrupted the nature and dynamics of radio practice which demands, that traditional radio firms adapt corporate credibility profiles to meet the 
new media environment. This provides a new wave of hope and opportunity for traditional electronic media to survive and create value for themselves and their stakeholders. Indeed, existing research on identity building and management of media brands is largely biased towards the consumers' personal identities and attributes rather than that of the organizations (Hollenbeck \& Kaikati, 2012; Bargh et al., 2002).

Abd-El-Salam et al. (2013) equated corporate image to brand credibility whilst Nguyen (2006) considers corporate image as an important factor in evaluating firm credibility, seen as an outcome of a customer's mental perception and impression about a brand. Zaim et al., (2010) reveal, that corporate image has a great influence on satisfaction and institutional credibility. A favourable firm image was found to be crucial for a firm's ability to maintain its position in the market and carve for itself, a strong reputation leading to improved customer retention and loyalty (Nguyen \& Leblanc, 2001). Source expertise and trustworthiness were seen as the primary considerations for a credible information source (Houdek, 2017). Shaw (2011) asserts that, organizations seeking success need to acquire a thorough knowledge of the current and potential markets for its products and services, and position itself in the minds of customers and consumers. Today's competitive marketplace demands the development of a strong and positive corporate visibility strategy towards attaining and sustaining a lasting competitive advantage (Arslan \& Altuna, 2010; Birtwistle \& Shearer, 2001).

Corporate visual identity (CVI) encompasses visual (tangible) elements such as the entity's logo, colour palette, typefaces (fonts), layout, photography and illustrations, advertising styles and even signs and symbols (Van den Bosch et al, 2005) and is used by companies, to project their quality, style and prestige to all their stakeholders, hence form an integral part of corporate identity (Melewar \& Saunders, 1999). It is a needed corporate expenditure for any organization's survival and existence and as such, firms that do not have the required capital to support such an investment may suffer the consequence that comes with it (Alshebil, 2007). Christensen and Askegaard (2001) found that CVI, besides differentiating firms from each other, has a positive effect on the sales and stakeholder recognition of firms.

In the last century, a large number of scholars and organizations have taken key interest in the multidimensional foundations of business identity (Balmar, 2001), seen in two spectacles, through the lenses of national culture and academic disciplines. Besides, researchers have broken down the 
concept of business identity into corporate identity, organizational identity and visual identity (Balmar, 2001). Corporate identity is an integrity concept through which organizations reveal their philosophy, conception, communication and behaviour for the purpose of distinguishing themselves from rivals (Karadeniz, 2009); the visual manifestation of a firm's reality conveyed through its name, logo, motto, colours, products, services, and other tangible evidences created by the organization and communicated (Argenti, 2015).

Asamoah-Gyadu (2008) emphasises, that the state of media plurality in Ghana places great demand on owners and managers of firms to continue to find new (ethical) ways of getting the masses to be loyal. The National Communication Authority (2016) puts authorized radio stations in Ghana at 481; Ashanti Region has 63 but only 46 are in operation with 36 in the Kumasi Metropolis. A cursory visitation to some radio stations reveals low or no presence of deliberate and proper corporate visibility strategy. For some, there are virtually little or no signage, that identify the radio station in the building they operate from to give directions. Similarly, there are also little or no uniquely distinctive features that differentiate each radio station from the other apart from basic signboards that contain the name of the station, assigned frequency and logo. The media landscape is not immune to rivalry and competition, therefore improved service and effective branding must complement adequate preparation and programming to ensure profitability (Asamoah-Gyadu, 2008) and continued patronage.

The concept, however, is not widely researched in the field of business and visual communication (Bartholmé \& Melewar, 2011). Van den Bosch et al., (2006) emphasized that CVI, is a field, that has received little attention in research hence, advocate for organizations to dedicate special attention to this endeavour which borders on issues of brand bonding, loyalty and credibility to ensure consistency. The aim of the research was to examine audience perception about corporate visibility of radio stations, and how it impacts on their image and credibility in the Kumasi Metropolis. Considering the concept relationships separately, the following hypotheses were tested:

H1: There is a statistically significant relationship between corporate visibility and corporate image among radio stations in the Kumasi Metropolis. 
H2: There is a statistically significant relationship between corporate visibility and radio station's credibility in the Kumasi Metropolis.

\section{Method}

The quantitative approach was utilized in the collection of data based on self-administered questionnaire in a survey. The population of the Kumasi Metropolis (KMA), for the study is estimated about 1,730,249 in 2015 (Metropolitan Authority, www.kma.gov.gh) and the approximate radio listenership population of 83,000 at peak time (National Communications Authority (NCA, 2016). Based on random sampling technique the instrument was distributed to managers of radio stations and radio listeners. This technique chosen, due to its suitability for cases that are particularly informative, make enumerating larger populations, possible (Morse and Niehaus, 2009). This study sampled 385 radio listeners and managers of the major radio stations within the KMA, after seeking their consent and assuring confidentiality.

\section{Results and Discussion}

The results were analyzed, generating descriptive statistics and inferential analyses. Table 1 details the sample characteristics.

Table 1 Sample characteristics

\begin{tabular}{|l|l|l|l|}
\hline Variable & Categories & Frequency & Percentage (\%) \\
\hline Gender & Male & 201 & 52.2 \\
\cline { 2 - 4 } & Female & 184 & 47.8 \\
\hline \multirow{4}{*}{ Age } & $18-24$ & 175 & 45.5 \\
\cline { 2 - 4 } & $25-31$ & 145 & 37.7 \\
\cline { 2 - 4 } & $32-38$ & 27 & 7 \\
\cline { 2 - 4 } & $39-45$ & 31 & 8.1 \\
\cline { 2 - 4 } & 46 and above & 7 & 1.8 \\
\hline \multirow{3}{*}{$\begin{array}{l}\text { Educational } \\
\text { background }\end{array}$} & Basic & 9 & 2.3 \\
\cline { 2 - 4 } & Secondary & 31 & 8.1 \\
\cline { 2 - 4 } & Tertiary & 345 & 89.6 \\
\hline \multirow{4}{*}{$\begin{array}{l}\text { Preferred radio } \\
\text { station (FM) }\end{array}$} & Luv & 93 & 24 \\
\cline { 2 - 4 } & Focus & 60 & 15.6 \\
\cline { 2 - 4 } & Nhyira & 48 & 12.5 \\
\cline { 2 - 4 } & Silver & 37 & 9.6 \\
\hline \multirow{2}{*}{} & & &
\end{tabular}




\begin{tabular}{|l|l|l|l|}
\hline & YFM & 24 & 6.2 \\
\cline { 2 - 4 } & Hello & 19 & 4.9 \\
\cline { 2 - 4 } & Angel & 18 & 4.8 \\
\cline { 2 - 4 } & Kessben & 17 & 4.4 \\
\cline { 2 - 4 } & Abusua & 12 & 3 \\
\cline { 2 - 4 } & Others & 57 & 15 \\
\hline
\end{tabular}

The study involved 385 respondents who filled the questionnaire of which 52.25\% were males and $47.8 \%$ were females. Majority (83.2) of respondents ranged between 18 and 31 whilst a huge majority has tertiary education (89.6\%). It is not surprising therefore that majority (41.6) preferred the first two radio stations which mostly broadcast in English and close to a major University.

On respondents' view on their preferred Radio Station's Corporate Image (Table 2), majority (76.7\%), at least agreed, that the station offers high quality services to its audience and partners with $85.2 \%$ at least agreeing to a much better service. Majority of respondents (47.5\%), at least disagrees with $36.4 \%$ unsure of programmes and activities appealing to people across every social class and age category. On whether the station has a wider geographic coverage than most, majority were not sure (52.2\%) and those who agreed were $40.8 \%$. Also, majority (47.5\%) agreed that the station's programmes and activities appeal to people across every social class and age category whilst $36.4 \%$ were not sure. Majority of respondents (66.5\%), at least agreed, that the management and staff are very effective and real with people's concerns, whiles only $38.9 \%$ at least agreed that they make listening to radio very practical, experiential and exciting.

Table 2 Radio Station's Corporate Image

\begin{tabular}{|c|c|c|c|c|c|}
\hline Statements & 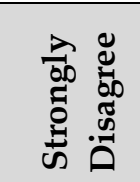 & 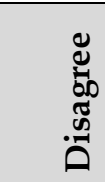 & $\begin{array}{l}0 \\
\vdots \\
\omega \\
0 \\
Z\end{array}$ & 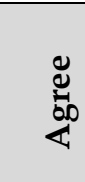 & 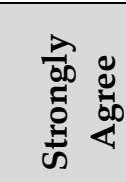 \\
\hline & $\%$ & $\%$ & $\%$ & $\%$ & $\%$ \\
\hline $\begin{array}{l}\text { 1. The station offers high quality services to its audience } \\
\text { and partners }\end{array}$ & 0 & 0 & 23.4 & 62.3 & 14.3 \\
\hline $\begin{array}{l}\text { 2. It provides a much better service to her target } \\
\text { audience }\end{array}$ & 0 & 3.9 & 11.9 & 74.8 & 9.4 \\
\hline 3. It has a wider geographic coverage than most & 0 & 7 & 52.2 & 40.8 & 0 \\
\hline $\begin{array}{l}\text { 4. The station's programs and activities appeal to people } \\
\text { across every social class and age category }\end{array}$ & 0 & 47.5 & 36.4 & 16.1 & 0 \\
\hline
\end{tabular}




\begin{tabular}{|l|l|l|l|l|l|l|}
\hline $\begin{array}{l}\text { 5. } \\
\text { The management and staff are very effective and real } \\
\text { with people's concerns }\end{array}$ & 4.2 & 2.3 & 27 & 59.2 & 7.3 \\
\hline $\begin{array}{l}\text { 6. } \\
\text { They make listening to radio very practical, } \\
\text { experiential and exciting }\end{array}$ & 3.9 & 13.2 & 43.9 & 20.5 & 18.4 \\
\hline
\end{tabular}

On respondents' perception about preferred Radio Station's Credibility (Table 3), firstly, less than half $(42.3 \%)$ at least agreed that it has staff who possess a great amount of media experience whilst $46.2 \%$ were not sure. Secondly, majority of respondents $(70.9 \%)$ at least agreed that the station demonstrates honesty, integrity and professionalism. Thirdly, many respondents (59.7\%) were not sure that it demonstrates consistent corporate behaviour internally and externally. Furthermore, $48.3 \%$ and $44.2 \%$ of respondents were not sure and at least agreed respectively, that it has an appreciable level of expertise in the media industry. More so, $49.4 \%$ at least agreed whilst $41.8 \%$ were not sure respectively, that they trust the content of programmes, the staff and information received from their favourite radio station. Majority of respondents (54.3\%) agreed that it is supportive of lawfulness, ethics and governance. Also, majority of respondents (43.9\%) agreed that the station is quick to apologize and withdraw any bad information churned out once they notice it to be untrue, whiles also majority (61\%) were not sure that it demonstrates social and environmental responsibility.

Table 3 Radio Station's Credibility

\begin{tabular}{|c|c|c|c|c|c|}
\hline Statements & 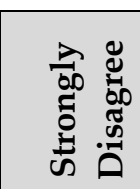 & 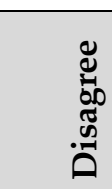 & 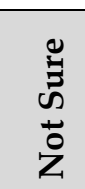 & 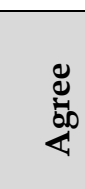 & 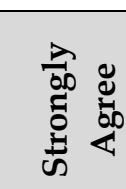 \\
\hline & $\%$ & $\%$ & $\%$ & $\%$ & $\%$ \\
\hline $\begin{array}{l}\text { 1. It has staff who possess a great amount of media } \\
\text { experience. }\end{array}$ & 0 & 11.4 & 46.2 & 37.1 & 5.2 \\
\hline $\begin{array}{l}\text { 2. The station demonstrates honesty, integrity and } \\
\text { professionalism }\end{array}$ & 0 & 9.1 & 20 & 57.4 & 13.5 \\
\hline $\begin{array}{l}\text { 3. It demonstrates consistent corporate behaviour } \\
\text { internally and externally }\end{array}$ & 0 & 6.8 & 59.7 & 25.2 & 8.3 \\
\hline $\begin{array}{l}\text { 4. It has an appreciable level of expertise in the media } \\
\text { industry }\end{array}$ & 0 & 7.5 & 48.3 & 42.1 & 2.1 \\
\hline $\begin{array}{l}\text { 5. I trust the content of programs, the staff and } \\
\text { information received from my favourite radio station. }\end{array}$ & 0 & 8.8 & 41.8 & 43.4 & 6 \\
\hline
\end{tabular}




\begin{tabular}{|c|c|c|c|c|c|}
\hline 6. It is supportive of lawfulness, ethics and governance & 5.7 & 28.6 & 11.4 & 54.3 & 0 \\
\hline $\begin{array}{l}\text { 7. The station is quick to apologize and withdraw any } \\
\text { bad information churned out once they notice it to be } \\
\text { untrue }\end{array}$ & 0.5 & 21.8 & 33.8 & 43.9 & 0 \\
\hline $\begin{array}{l}\text { 8. It demonstrates social and environmental } \\
\text { responsibility }\end{array}$ & 0.3 & 4.2 & 61 & 34.5 & 0 \\
\hline
\end{tabular}

To measure the audience's perception of the radio stations' corporate visibility initiatives, the respondents were required to state the extent to which they agreed with or otherwise to a number of statements regarding corporate visibility. The result of this analysis is summarized in Table 4 below (where ' $\mathrm{CV}$ ' is the coefficient of variation and 'SD' is the standard deviation.

Table 4 Audience Perception about Radio Stations' Corporate Visibility

\begin{tabular}{|c|c|c|c|}
\hline Corporate Visibility Scale & Mean & SD & CV (in \%) \\
\hline $\begin{array}{l}\text { 1. The location is strategic and convenient for the public to reach } \\
\text { them easily. }\end{array}$ & 3.52 & 1.03 & 19.4 \\
\hline $\begin{array}{l}\text { 2. The image and reputation is an important influence on } \\
\text { people's choices. }\end{array}$ & 3.54 & 0.92 & 16.3 \\
\hline 3. Ownership and management structure attracts people to it. & 3.46 & 1.03 & 14.9 \\
\hline $\begin{array}{l}\text { 4. Its vision and mission statement guides the direction and } \\
\text { strategy of the firm. }\end{array}$ & 3.55 & 1.01 & 17.3 \\
\hline $\begin{array}{l}\text { 5. Its Mission is operationalized through program goals and } \\
\text { activities. }\end{array}$ & 3.36 & 1.08 & 18.6 \\
\hline 6. History of performance influences people's patronage. & 3.05 & 1.04 & 15.1 \\
\hline $\begin{array}{l}\text { 7. The external affiliation with other sister stations makes me } \\
\text { wants to listen to them always. }\end{array}$ & 3.40 & 0.96 & 17.4 \\
\hline 8. The location enables better service delivery to the public. & 3.25 & 1.10 & 20.5 \\
\hline $\begin{array}{l}\text { 9. The staff, buildings, events, cars, etc. are modern and } \\
\text { attractive. }\end{array}$ & 3.47 & 0.89 & 19.8 \\
\hline 10. It has adequate equipment and facilities. & 3.33 & 0.96 & 17.4 \\
\hline 11. The programs and events are relevant and people-oriented. & 3.62 & 0.81 & 20.4 \\
\hline $\begin{array}{l}\text { 12. It allows for public inputs and takes these public opinions to } \\
\text { serious consideration. }\end{array}$ & 3.93 & 0.94 & 19.3 \\
\hline $\begin{array}{l}\text { 13. It allows for regular communication and interaction with the } \\
\text { public which makes each other feel appreciated. }\end{array}$ & 3.88 & 0.85 & 15.5 \\
\hline
\end{tabular}


14. It has a well-managed and updated website and social media platform.

15. The colours appeal to me.

16. The logo does not appeal to me.

17. The branding of the station appeals to me.

18. Their tag line or slogan appeals to me.

19. The corporate image is enhanced by excellent customer relationship.
3.88

0.96

3.81

0.84

$\begin{array}{ll}3.67 & 0.87\end{array}$

$3.76 \quad 0.77$

$3.69 \quad 0.86$

$3.63 \quad 1.00$

$3.69 \quad 0.655$
18.2

15.8

19.6

14.8

17.2

18.5

Grand Mean Score

.655

The grand mean score rating of 3.69 in Table 4 indicates to a larger extent, an agreement on the part of respondents on the existence of corporate visibility practices among the surveyed radio firms. The two questions on public interaction and regular updates on their website with good social media presence (items 13 and 14) each produced the highest mean score value of 3.88 while the item (item 6) on the history of performance influencing people's patronage yielded the lowest mean value of 3.05 .

Consequently, the highest variability in response was on (item 8) the location of these firms enabling better service delivery to the public; which yielded a coefficient of variation (CV) of 20.5. This implies that, the responses given by the sampled population were generally positive, consistent and in agreement with each other. This is an indication of the public's positive verdict on the surveyed firms' corporate visibility strategies. Invariably, the pay-offs from good corporate visibility from literature cannot be over-emphasized as literature abundantly demonstrates that, positive corporate visibility eventually leads to some positive outcomes including good market positioning (Shaw, 2011), lasting competitive advantage (Arslan \& Altuna, 2010; Birtwistle \& Shearer, 2006) and leaves behind a good impression of quality on the minds of customers (Keller, 2003; Zamardino \& Goodfellow, 2007). Keller (1993) argued that there is a positive relationship between corporate visibility and consumer loyalty.

The simple frequency analysis conducted reveals, that there is some good level of public awareness of the visibility drive that these radio stations are embarking on as there is evidence of agreement among the respondents of good corporate visibility by these firms. 


\section{Effects of Corporate Visibility on Radio Stations' Image}

A test for the relationship between corporate visibility and firm image based on the hypothesis:

H1: There is a statistically significant relationship between corporate visibility and corporate image among radio stations in the Kumasi Metropolis.

The result of the analysis is summarized in Table 5:

Table 5 Regression Result of Corporate Visibility versus Corporate Image

\begin{tabular}{|c|c|c|c|c|c|c|}
\hline \multicolumn{7}{|c|}{ i. $\quad$ Goodness of Fit } \\
\hline Model & R Score & R-Square & \multicolumn{2}{|c|}{ Adjusted R Square } & \multicolumn{2}{|c|}{ Standard Error of the Estimate } \\
\hline 1 & .694 & .435 & \multicolumn{2}{|l|}{.443} & \multicolumn{2}{|l|}{.04387} \\
\hline \multicolumn{7}{|c|}{ Overall Significance } \\
\hline \multicolumn{2}{|l|}{ Model } & Sum of Squares & $\mathrm{df}$ & Mean Square & F-test & Sig. (p-value) \\
\hline $\begin{array}{l}\mathrm{R} \\
\mathrm{R} \\
\mathrm{T}\end{array}$ & $\begin{array}{l}\text { Regression } \\
\text { Residual } \\
\text { Total }\end{array}$ & $\begin{array}{l}0.058 \\
0.063 \\
0.132\end{array}$ & $\begin{array}{l}1 \\
33 \\
35\end{array}$ & $\begin{array}{l}0.056 \\
0.004\end{array}$ & 28.274 & 0.000 \\
\hline \multicolumn{7}{|c|}{ iii. Composite Score Test } \\
\hline \multirow{2}{*}{\multicolumn{2}{|c|}{ Model }} & \multicolumn{2}{|l|}{$\begin{array}{l}\text { Unstandardized } \\
\text { Coeffic. }\end{array}$} & $\begin{array}{l}\text { Standardized } \\
\text { Coefficients }\end{array}$ & \multirow[t]{2}{*}{ T-Test } & \multirow[t]{2}{*}{ Sig. (p-value) } \\
\hline & & B & $\begin{array}{l}\text { Std. } \\
\text { Error }\end{array}$ & Beta & & \\
\hline \multicolumn{2}{|c|}{$\begin{array}{l}1 \text { (Constant) } \\
\text { Corporate Visibility }\end{array}$} & $\begin{array}{l}0.355 \\
0.513\end{array}$ & $\begin{array}{l}0.67 \\
0.98\end{array}$ & .655 & $\begin{array}{l}5.152 \\
5.322\end{array}$ & $\begin{array}{l}0.000 \\
0.000\end{array}$ \\
\hline
\end{tabular}

Predictors: (Constant), Corporate Visibility; Dependent Variable: Corporate Image

Table 5 shows that, corporate visibility has some statistically significant influence on corporate image as the test indicates, that corporate visibility explains $43.5 \%$ of the variation in corporate image $\left(R^{2}=0.435\right)$. The standardized regression coefficient $(\beta)$ value of the computed (composite index) scores of corporate visibility was 0.655 with a t-test score of 5.322 and a significance level of $\mathrm{p}=0.000$. The results also show a linear dependence of corporate image on corporate visibility.

The regression equation of this result thus:

$\mathrm{CV}=\beta_{0}+\beta_{1} \mathrm{X}$ 
$\mathrm{CV}=0.355+0.655 \mathrm{CI}$

Where $\mathrm{CV}=$ corporate visibility, $\beta_{0}=$ constant and $\mathrm{CI}=$ corporate image.

This finding agrees with previous studies which found a positive relationship between corporate visibility and corporate image (Olins 2000; Lewis 2000; Pauvit 2000; Balmer 2001, Balmer and Greyser 2003). Efforts aimed at enhancing corporate visibility correlate statistically and significantly with a positive corporate image improvement. Therefore, the hypothesis that there is a statistically significant relationship between corporate visibility and corporate image among radio stations in the Kumasi Metropolis is supported by the current study.

In determining the relationship between corporate visibility and firm image, the results of the regression analysis show that, there is a statistically significant relationship between the two variables. As literature on corporate image suggests, firm performance is influenced by the feelings, attachment and beliefs people have in their minds about an organization. Therefore, managing corporate image involves a fabrication and projection of a desired picture of the organization; deliberately constructed to influence the public (Olins 2000, Lewis 2000, Pauvit 2000, Balmer 2001, Balmer and Greyser 2003). The study reveals $68 \%$ of respondent perceived emotionally attached to the image of the radio stations and would readily patronize their events and programmes. Notwithstanding, a sizable number (40\%) are quite sceptical about the future prospects and growth of these radio stations.

\section{Effects of Corporate Visibility on Radio Stations' Credibility}

To assess the influence of corporate visibility on firm credibility, a regression analysis was conducted with a relevant hypothesis formulated as follows:

H2: There is a statistically significant relationship between corporate visibility and radio station's credibility in the Kumasi Metropolis.

The result from the regression analysis to test this relationship is summarized in Table 6: 
Table 6 Effects of Corporate Visibility on Radio Stations' Credibility

\begin{tabular}{|c|c|c|c|c|c|c|}
\hline \multicolumn{7}{|c|}{ Goodness of Fit } \\
\hline Model & R Score & R-Square & \multicolumn{2}{|c|}{ Adjusted R Square } & \multicolumn{2}{|c|}{$\begin{array}{l}\text { Standard Error of the } \\
\text { Estimate }\end{array}$} \\
\hline 1 & .342 & .144 & \multicolumn{2}{|l|}{.114} & \multicolumn{2}{|l|}{.05624} \\
\hline \multicolumn{7}{|c|}{ Overall Significance } \\
\hline \multicolumn{2}{|l|}{ Model } & Sum of Squares & $\mathrm{df}$ & Mean Square & F-test & Sig. (p-value) \\
\hline \multicolumn{2}{|c|}{$\begin{array}{ll}1 & \text { Regression } \\
& \text { Residual } \\
& \text { Total } \\
\end{array}$} & $\begin{array}{l}0.016 \\
0.111 \\
0.131\end{array}$ & $\begin{array}{l}1 \\
33 \\
35\end{array}$ & $\begin{array}{l}0.015 \\
0.004\end{array}$ & 5.538 & 0.022 \\
\hline \multicolumn{7}{|c|}{ Composite Score Test } \\
\hline \multirow{2}{*}{\multicolumn{2}{|c|}{ Model }} & \multicolumn{2}{|c|}{ Unstandardized Coeffic. } & $\begin{array}{l}\text { Standardized } \\
\text { Coefficients }\end{array}$ & \multirow[t]{2}{*}{ T-Test } & \multirow[t]{2}{*}{ Sig. (p-value) } \\
\hline & & $\mathrm{B}$ & Std. Error & Beta & & \\
\hline \multicolumn{2}{|c|}{$\begin{array}{c}\text { (Constant) } \\
\text { Corporate } \\
\text { Visibility }\end{array}$} & $\begin{array}{l}0.551 \\
0.211\end{array}$ & $\begin{array}{l}0.65 \\
0.91\end{array}$ & .322 & $\begin{array}{l}6.495 \\
2.436\end{array}$ & $\begin{array}{l}0.000 \\
0.025\end{array}$ \\
\hline
\end{tabular}

Predictors: (Constant). Corporate Visibility; Dependent Variable: Corporate Credibility

Form the results, corporate visibility explains $14.4 \%$ of the variability in corporate credibility of radio stations in the Kumasi Metropolis; which is statistically significant $\left(R^{2}=0.144\right)$. It yielded a standardized regression coefficient $(\beta)$ value of corporate visibility at 0.342 with a t-test value of 2.436 which is significant at $\mathrm{p}=0.025$. The results suggest a linear dependence of corporate image on corporate visibility, supported by earlier findings (Nguyen \& Leblanc, 2001; Zaim et al., 2010). Thus far, the hypothesis that there is a statistically significant relationship between corporate visibility and radio station's credibility in the Kumasi Metropolis is supported by this study. This is summarized by the regression equation:

$\mathrm{CV}=\beta_{0}+\beta_{1} \mathrm{X}$

$\mathrm{CV}=0.551+0.322 \mathrm{CC}$

Where $\mathrm{CV}=$ corporate visibility, $\beta_{0}=$ constant and $\mathrm{CI}=$ corporate credibility. 


\section{Conclusion}

Corporate visibility was found to influence corporate image and credibility in a positive and statistically significant relationship of radio stations in Kumasi. About $71 \%$ affirm that stations demonstrate honesty, integrity and professionalism. The statistically significant relationship is reflective of other findings (Nguyen \& Leblanc, 2001; Zaim et al., 2010). The results show that a firm's corporate visibility is partly dependent on its location, physical structure, leadership and management approach as well as quality and competence of employees. The implication is that, increasing corporate visibility could strengthen corporate image and credibility.

\section{Suggestions}

Radio stations are expected to play a vital role in information dissemination, public education and entertainment. The media contributes in improving public awareness and participation in socioeconomic issues. It should be a hub for continuous research, public education and scrutiny to inform policies about media practice in Ghana. To this end, management should ensure and maintain acceptable physical presence that appeals to the public and integrate innovativeness in their operations to influence public perception and choice.

\section{Acknowledgement}

The authors wish to thank the study participants for their valuable contributions to this work.

\section{References}

Abd-El-Salam M.E., Shawky Y.A. \& El-Nahas.T. (2013). The impact of corporate image and reputation on service quality, customer satisfaction and customer loyalty: testing the mediating role. Case analysis in an international service company. The Business \& Management Review, Vol.3 Number-2, January

Alshebil, S.A., (2007). Consumer perceptions of rebranding: the case of logo changes. The University of Texas at Arlington.

Argenti, P. A., (2015). Corporate Communication, 7th ed. McGraw-Hill Education. ISBN-13: 9780073403274 
Asamoah-Gyadu, J. K., (2008). Into the World through New Media: African-initiated Pentecostalism and Cyberspace Witness. In International Conference on New Media and Religious Transformations in Africa. Abuja, Nigeria (pp. 10-12).

Arslan F. M. \& Altuna, O. K., (2010). The Effect of Brand Extensions on Product Brand Image, Journal of Product \& Brand Management. Vol. 19. Iss. 3pp. 170-180. Emerald.

AlShebil, S.A., (2007). Consumer perceptions of rebranding: the case of logo changes. The University of Texas at Arlington.

Balmer, J.M.T. \& Greyser, S.A. (2003). Revealing the corporation: Perspectives on identity, image, reputation, corporate branding and corporate level marketing. London: Routledge.

Balmer, J.M.T. (2001). 'Corporate identity, corporate branding and corporate marketing. Seeing through the fog', European Journal of Marketing, 35 (3/4), pp.248-291.

Bargh, J., McKenna, K. Y. A. \& Fitzsimons, G. M. (2002). Can you see the real me? Activation and selfexpression of the 'true self' on the internet. Journal of Social Issues, 58(1), 33-48.

Bartholmé, $\underline{\text { R. H. }}$ and Melewar, T. C. (2011). "Remodelling the corporate visual identity construct: A reference to the sensory and auditory dimension", Corporate Communications: An International Journal, Vol. 16(1):53 - 64 .

Birtwistle G. \& Shearer, L., (2006). Consumer perception of five UK fashion retailers, Journal of Fashion Marketing and Management, Vol. 5 Iss: 1

Brammer, S., \& Millington, A. (2006). Firm size, organizational visibility and corporate philanthropy: An empirical analysis. Business Ethics: A European Review, 15(1), 6-18.

Christensen, L.T. \& Askegaard, S. (2001). 'Corporate identity and corporate image revisited. A semiotic perspective', European Journal of Marketing, 35 (3/4), pp.292-315.

Hollenbeck, C. R. \& Kaikati, A. M. (2012). Consumers' use of brands to reflect their actual and ideal selves on Facebook. International Journal of Research in Marketing, 29(4), 395-405.

Houdek, P. (2017). Is Behavioral Ethics Ready for Giving Business and Policy Advice? Journal of Management Inquiry, 1056492617712894.

Karadeniz, M., (2009). The importance of creating a successful corporate identity and corporate image for enterprises in marketing management. Deniz Bilimleri ve Mühendisliği Dergisi, 5(3).

Keller, K. L. (2003). Strategic brand management: Building, measuring and managing brand equity. 2nd edn. Upper Saddle River: Prentice Hall. 
Journal of Business Management and Economic Research (JOBMER), vol.3, issue.7, pp.1-16

Keller, K. L., (1993). Conceptualizing, Measuring, and Managing Customer-Based Brand Equity: Journal of Marketing, Vol. 57, No. 1 (Jan., 1993), pp. 1-22: American Marketing Association.

Kostamo, U., (2013). The New Era of Corporate Marketing: Building and managing Corporate Identity in Social media. Department of Marketing. Aalto University of School of Business

Lewis, T., (2000). Branding, celebritization and the lifestyle expert. Cultural Studies, 24(4), pp. 580598

Melewar, T.C. (2003). 'Determinants of the corporate identity construct: a review of the literature', Journal of Marketing Communications, 9, pp.195-220.

Melewar, T. C. and Saunders, J. (1999). International corporate visual identity: standardization or localization? Journal of International Business Studies, Fall Vol. 30 (3):583.

Morse, J.M. and Niehaus, L. (2009). Mixed method design: Principles and procedures (Vol. 4).

Left Coast Pr.

National Communications Authority, (2016). List of Authorised VHF-FM Radio Stations in Ghana, Third Quarter, 2016. [www.nca.org.gh/media-and-news/news/industry-information-august2016/ [Accessed, 9th January, 2018]

Nguyen, N. \& LeBlanc, G. (2001). Image and Reputation of Higher Education Institutions in Students' Retention Decisions. The International Journal of Educational Management, 15(6/7), 303-311.

Nguyen, N. (2006). The Collective Impact of Service Workers and Servicescape on the Corporate Image Formation. International Journal of Hospitality Management, 25(2), 227-44.

Olins, W. (2000). Why brands are taking over the corporation. In: Schultz, M., Hatch, M.J. and Larsen, M. H. (eds) The Expressive Organization: Linking Identity, Reputation, and the Corporate Brand. Oxford: Oxford University Press.

Pauvit, J., (2000). Brand New. V\& A Publications, London

Shaw, S., (2011). Airline Marketing and Management, 7th edition, Ashgate

Van den Bosch, A. L. M., Elving, W. J. L., \& de Jong, M. D. (2006). The impact of organizational characteristics on corporate visual identity. European Journal of Marketing, 40(7/8), pp 870885

Yang, A., \& Kent, M. (2014). Social media and organizational visibility: A sample of Fortune 500 corporations. Public Relations Review, 40(3), 562-564. 
Journal of Business Management and Economic Research (JOBMER), vol.3, issue.7, pp.1-16

Zaim, S., Turkyilmaz, A., Tarim, M., Ucar, B., \& Akkas, O. (2010). Measuring Customer Satisfaction in Turk Telecom Company Using Structural Equation Modeling Technique. Journal of Global Strategic Management, 7, (June), 89-99.

Zamardino, M., \& Goodfellow, S. (2007). Importance of Brand Awareness and Brand Loyalty in Assessing Purchase Intentions of 23. Consumer. International Journal of Business and Social Science, 4(5), 167-171. 